\title{
On the translation of boundary-crossing events: Evidence from an experiment with German and Spanish translation students
}

\author{
Paula Cifuentes-Férez \\ Universidad de Murcia, Spain \\ paulacf@um.es \\ Teresa Molés-Cases \\ Universitat Politècnica de València, Spain \\ temoca1@upv.es
}

\begin{abstract}
This paper deals with the translation of motion events between typologically similar and different languages, a research field which has been generally approached from the Thinking-for-translating hypothesis. Here we present a student-based experiment focused on the translation of boundary-crossing events (specifically: 'manner verb + into + a bounded space') from English (a satellite-framed language) into German (a satellite-framed language) and Spanish (a verb-framed language). The aim is to investigate whether translation students interpret correctly and translate both the boundary-crossing and the Manner information. For this purpose, a group of German and Spanish translation students were asked to translate a series of excerpts from English narrative texts into their respective mother tongues. The results suggest that the way translation students deal with these phenomena is mainly influenced by the lexicalization patterns of their mother tongues, but the nature of the event itself and the context also seem to be key in some cases.
\end{abstract}

Keywords: Motion events, boundary-crossing, Manner, Thinking-for-translating, translation students.

\section{Resumen}

El presente artículo analiza la traducción de eventos de movimiento entre lenguas de igual y de distinto grupo tipológico, un campo de investigación que se ha estudiado principalmente en la línea de la hipótesis del Pensar para traducir. Esta contribución presenta un experimento con estudiantes en torno a la traducción de eventos de movimiento que incluyen cruce de límites (específicamente: 'verbo de manera + into 
+ espacio delimitado') en inglés (lengua de marco satélite) y su traducción al alemán (lengua de marco satélite) y al español (lengua de marco verbal). El objetivo principal es analizar si los estudiantes de traducción interpretan correctamente y traducen tanto la información sobre el cruce de límites como sobre la Manera de movimiento. Para ello, se pidió a un grupo de estudiantes de traducción alemanes y españoles que tradujeran una serie de fragmentos de novelas en inglés a sus respectivas lenguas maternas. Si bien los resultados confirman que la forma en que los estudiantes de traducción resuelven estos fenómenos está condicionada por los patrones de lexicalización característicos de su lengua materna, la naturaleza de los eventos de movimiento y el contexto también parecen ser clave en algunos casos.

Palabras clave: eventos de movimiento, cruce de límites, Manera, Pensar para traducir, estudiantes de traducción.

\section{Introduction}

Languages differ in the way they filter reality through language. One of the domains which has received substantial attention in Linguistics in general and in Cognitive Linguistics in particular is motion. As argued in Filipović \& Ibarretxe-Antuñano (2015: 527), among the reasons why linguists have dealt with this phenomenon, we find that motion expressions "are considered basic and omnipresent" and are "paramount to human cognition [...] and as such space and motion have been considered a crucial testing ground for linguistic behaviour".

Motion event linguistic framing and translation research has come a long way since Talmy published his seminal work on the typology of motion events (1985, 1991, 2000) and Slobin proposed his Thinking-for-speaking/translating hypotheses (1996, 2003). In the literature on the linguistic encoding of motion events (see IbarretxeAntuñano \& Filipović, 2013, for a detailed review) and on linguistic relativity research using motion events (see, for example, Feist, 2016, for a summary), most of the existing studies compare typologically different languages, but we do find some studies which focus on languages belonging to the same typological group (e.g., Ibarretxe-Antuñano, 2004; Kopecka, 2010; Hijazo-Gascón \& Ibarretxe-Antuñano, 2013; Verkerk, 2014; Lewandowski, 2018). Research on the translation of motion events pertaining to typologically similar languages is also scarce (see Cifuentes-Férez (2018) for an updated review on translation of motion events), with a few exceptions, for example, Filipović (1999, 2008) on English into Serbo-Croatian translation and vice versa, IbarretxeAntuñano (2003) on English into Basque and Spanish translation, Sugiyama (2005) on English into Japanese and French translation, and Lewandowski and Mateu (2016) on English into Polish and German translation. It must be noted here that the 
perspective adopted in these contributions varies: while Ibarretxe-Antunano (2003) and Sugiyama (2005) compare the translation of two target languages of the same typology (verb-framed languages), Filipović $(1999,2008)$ and Lewandowski and Mateu (2016) compare source and target languages belonging to the same typological group (satellite-framed). Furthermore, although research on motion encoding has extensively dealt with the boundary-crossing constraint (Aske, 1989; Slobin \& Hoiting, 1994), whereby Spanish and other verb-framed languages do not allow the use of manner verbs when a boundary is crossed, that is, when an end-of-path location or a telic path is predicated. To our knowledge, research on the translation of motion has not devoted any attention to the translation of boundary-crossing events.

The present article thus aims to fill a gap in the literature on the translation of motion events by addressing the issue of the translation of boundary-crossing events and including translations from English into two languages: German (satellite-framed) and Spanish (verb-framed). In other words, the study reported in this paper focuses on the difficulties pertaining to the translation of motion events between typologically similar (English-German) and typologically different (English-Spanish) languages, with regard to the correct interpretation and rendering of boundary crossing events ('manner verb + into + bounded space) by student translators. The results of this study indicate that boundary-crossing events seem to be harder to interpret and translate correctly into Spanish than into German. Additionally, our data suggest that Spanish student translators might be more concerned with rendering the information conveyed in the manner verb and may overlook that a Figure has indeed crossed a boundary (expressed in prepositional phrases) and, thus, changed its location. Moreover, our findings support previous findings on the translation of Manner of motion, thus contributing to research on both inter-typological and intra-typological translation scenarios.

This paper is organized as follows. In Section 2, the context of this research will be introduced, namely, the Talmian typology of motion events (Talmy, 1991, 2000), the boundary-crossing constraint (Aske, 1989; Slobin \& Hoiting, 1994), and a brief overview of research on the translation of motion events based on Slobin's (2003) Thinking-for-translating hypothesis. Then, Section 3 presents the study on the translation of boundary-crossing motion events from English into German and Spanish. After describing the research question, the hypotheses, and the methodology, we will report the results and discuss the main findings. Finally, in Section 4, some relevant conclusions and future avenues for research will be presented 


\section{Theoretical background}

\subsection{Lexicalisation patterns for motion events and the boundary-crossing constraint}

It is widely known among Cognitive Linguistics scholars that Talmy $(1991,2000)$ distinguishes between two types of languages, depending on where the Path of motion component (the core or main component of a motion event, according to Talmy's theory) is encoded or expressed linguistically. Satellite-framed languages such as English and German typically encode Path in a satellite (usually a particle or a prefix) and Manner in the verb root. In contrast, verb-framed languages such as Spanish and French usually encode Path in the verb and Manner in adjuncts. This typological contrast is illustrated in example (1).

a. English: The bird flew out of the cage

b. German: Der Vogel flog aus dem Käfig

The.M bird fly.PAST.3SG from the.M.DAT cage

c. Spanish: El pájaro salió de la jaula (volando)

The.M bird exit.PAST.3SG from the.F cage (fly.GER)

English and German, being satellite-framed languages, express the Path component of the motion event by means of particles heading prepositional phrases (i.e., out of the cage in English and aus dem Käfig 'out of the cage' in German), while Spanish encodes the Path of motion in the verb root (i.e., salir 'to exit') and may express Manner in an optional constituent, as in the gerund volando 'flying'. However, when the motion event involves a non-telic Path, that is, when the Figure does not cross a boundary (contrary to what happens with the verbs enter, cross, or exit), apart from some language particularities (see, for example, Aurnague (2011), Cappelle (2012), Iacobini \& Fagard (2011) and Martínez-Vázquez (2013)), verb-framed languages allow the use of manner verbs as exemplified in (2) and (3).

$$
\begin{aligned}
& \text { Paula y Alberto corrieron hasta el colegio } \\
& \text { Paula and Alberto run.PAST.3PL up.to the.M school } \\
& \text { 'Paula and Alberto run up to the school' }
\end{aligned}
$$$$
\text { Losniños bailan en el salón }
$$ 
On the translation of boundary-crossing events: Evidence from an experiment with German and Spanish translation students

The.PL kids dance.PRES.3PL in the.M dining-room

'The kids are dancing in the dining-room'

In this way, in Spanish the use of correr 'to run' is allowed in (2) because the preposition hasta 'up to' implies that the Figures (Paula and Alberto) reach the school but do not enter it, that is, they do not run into the school. In addition, in (3) the manner verb bailar 'to dance' can be used because the sentence describes an activity taking place in a specific location and no change of location is predicated.

The impossibility for Spanish to use manner verbs in boundary-crossing situations was first noticed by Aske (1989), who stated that Spanish can use a manner verb with locative path phrases as English does, but, unlike English, manner verbs cannot be employed when an end-state of the Figure is predicated. This restriction gained its name as the boundary crossing constraint in Slobin and Hoiting (1994), due to the authors' distinction between path-focus expressions, as in example (2), and boundaryfocus expressions, as in example (1), and it is the term we are going to use throughout this paper.

Further research on motion events, such as studies carried out by Naigles et al. (1998) and Özcaliskan (2015), has suggested that the use of manner verbs is allowed in Spanish and Turkish (another verb-framed language) when the motion refers to a punctual or sudden vertical boundary crossing such as the one in tirarse a la piscina 'to throw oneself into the pool'. Naigles et al. (1998) also noticed that when the boundarycrossing event was horizontal, Spanish used more path verbs than when the boundary was vertical. Özcaliskan's (2015) findings indicated that Turkish speakers use manner verbs when describing quick or instantaneous acts depicted in pictures as in leaping over a hurdle, but not when describing motion events whose time span is longer as in flying out of a jar. Therefore, it seems that axis or orientation, speed of motion and/or duration of the motion event are factors which should be taken into account to better understand the boundary-crossing constraint and might be interesting to consider them when investigating both inter- and intra-typological differences in the linguistic expressions of motion events.

All these typological differences in the expression of motion events, as noted by Slobin $(1991,1996)$ and other scholars, have a significant impact on the narrative or rhetorical style of languages. More specifically, narratives in satellite-framed languages seem to devote more attention to how the motion event takes place, resulting in very dynamic descriptions of those events (i.e., highly rich in details of manner of motion and trajectories), whereas narratives in verb-framed languages appear to devote less 
attention to the dynamics of the motion event, instead describing static settings and the result of the motion event (cf. Cifuentes-Férez, 2017).

The great interest in the linguistic expression of motion events across languages also reached research on second language acquisition. Learning a language, no matter whether it is the mother tongue (L1) or a second language (L2), requires the learner to pay attention to the aspects of experience which are easily encoded in the language being acquired. In this way, second language learners have to rethink for speaking in their L2 (e.g., Cadierno \& Ruiz, 2006; Cadierno \& Robinson, 2009; Robinson \& Ellis, 2008; Cadierno, 2010) since L2 lexicalisation patterns for motion may be in competition with those of the learner's L1, especially in cases where the L1 and the L2 belong to different typological groups.

Cifuentes-Férez (2015) examined the acquisition of English motion constructions by Spanish student translators by means of inverse translation (that is, they were asked to translate a short narrative text from Spanish (L1) into English (L2)). Her data suggested that instruction on typological differences has a facilitating effect in the production of more target-like motion constructions (i.e., 'manner in the verb + path in satellite') as in the following boundary-crossing events: Lola jumped out of the jar and Timón crawled out of his cage. However, the author noticed that translators in training still face some problems with path expressions, such as out of (e.g. Lola ran out $[\mathrm{OF}]$ the tin; Timón jumped out $[\mathrm{OF}]$ the cage) and complex paths after a single motion verb, as has been also documented by other scholars (e.g., Cerda, 2010).

Inspired by a twelve picture linguistic description task used previously in Cadierno (2010) and Özcaliskan (2015), Alonso (2016) analysed the results of an interpretation task of boundary-crossing events by Spanish learners of L2 English and English native speakers. Her results showed that (a) English monolinguals chose the motion construction which is typical for satellite-framed languages; (b) Spanish learners of English use the L2 English lexicalisation pattern frequently in the scenes dive into a pool and tumble into net, which depict rapid or sudden motion; (c) pictures with over make participants more likely to choose manner verbs than those with in and out of; and (d) cross-linguistic influence is found especially in the case of into/out of + a bounded space in horizontal motion, such as into the house.

On the whole, research on first and second language acquisition of lexicalisation patterns of motion events has suggested that the duration of the event (punctual, rapid events vs. events extended in time) and the type of boundary crossing are important factors in the use of manner verbs in verb-framed languages, such as Spanish and Turkish. However, empirical research on the boundary-crossing constraint is still scarce and, as we shall see in the following subsection, to the best of our knowledge, 
On the translation of boundary-crossing events: Evidence from an experiment with German and Spanish translation students

research on the translation of motion events has not yet addressed this constraint in terms of the way student translators interpret and translate boundary-crossing events from their L2 into their L1.

\subsection{The Thinking-for-translating hypothesis}

In his Thinking-for-translating hypothesis, Slobin (2003) discussed the consequences that the different linguistic framing of motion events may have in the translation process between similar or typologically different languages and has observed the general tendency of translators to follow the rhetorical or narrative style of the target language. In other words, translators produce target texts which sound natural to the target audience (cf. Ibarretxe-Antuñano \& Filipovil, 2013; Cifuentes-Férez \& Rojo, 2015; Molés-Cases, 2016, 2018; Cifuentes-Férez, 2018). His investigations of English-Spanish translation have concluded that, overall, when translating from English into Spanish, Manner information is commonly omitted and Path information is usually changed or reduced. In contrast, when translating from Spanish into English, Path is frequently kept and Manner information is either kept or even added in the target text, "apparently finding the Spanish original too bland for English readers” (Slobin, 2003: 167).

Initially, Slobin $(1996,1997)$ focused on the translation of English and Spanish novels, comparing originals to their published translations, and pointed to the problems that translators have to face particularly in the case of translating from English into Spanish: the greater diversity of manner verbs in English and the boundary-crossing constraint, among others. In terms of the former, when translating motion events without boundary crossing, translators have to decide whether to express the Manner information conveyed in the English novel or not. If they opt to do so, Spanish translators tend to compensate for lexical gaps in the motion verb lexicon by including adjuncts. When translating boundary-crossing events, Spanish translators accommodate the demands of their mother tongue and use path verbs in order to be able to encode the boundary-crossing, omitting or reducing the Manner information encoded in the English manner verb in the source text.

In later work, Slobin (2005) widened his scope to include another nine languages besides English and Spanish: Dutch, German, Russian and Serbo-Croatian in the satellite-framed language group and French, Portuguese, Italian, Hebrew and Turkish in the verb-framed one. He examined the translation of several fragments from Chapter 6 of the English novel The Hobbit by Tolkien (1937). His results further support his previous findings regarding translations from English into Spanish and vice versa, and generalise them to a larger number of languages: verb-framed languages apparently 
are less concerned with Manner of motion than are satellite-framed languages, and they break complex paths or trajectories into several segments. In addition, when translating from English into verb-framed languages, it appears that there is a greater loss of both Path and Manner information than in translations from English into other satellite-framed languages.

Further studies on the translation of motion events using The Hobbit have been carried out by Ibarretxe-Antuñano (2003) on Basque and Spanish, Lewandowski and Mateu (2016) on Polish and German, and Alonso (2018) on Galician. IbarretxeAntuñano (2003) noticed intra-typological differences between Basque and Spanish both in terms of Manner and Path. With regard to the translation of manner verbs, Spanish translators tended to keep more Manner information than did Basque translators, although the translations usually involved the inclusion of a totally different Manner than the one expressed in the original English text; in other words, they tended to modulate Manner. In terms of Path, Basque translators provided richer descriptions of paths than did Spanish translators as Basque allows the use of more than two paths with motion verbs and including multiple paths is quite common. In these cases, IbarretxeAntuñano (2003) refers specifically to the term 'variation', rather than to 'differences'. Lewandowski and Mateu's (2016) study on translation of English into Polish and German also addressed intra-typological differences between these two satellite-languages. Their findings indicate that German exploits the satellite-framed pattern much more than Polish does, because German verb particles are more flexible than Polish prefixes when combining manner verbs and paths, and German has a richer inventory of resources for encoding Path. Moreover, the authors remarked that like Spanish, Polish uses a separate verb for each path segment. Directing our attention again towards verb-framed languages, Alonso (2018) dealt with English-into-Galician translation. Her data revealed that typological differences between English and Galician influenced the rendering of manner verbs and the choice of construction types. Accordingly, manner verbs were translated into Galician using four types of verbs, namely, manner, path, motion, and non-motion verbs and four main strategies were used when translating those manner verbs: translation of only a portion of the Manner information, translation of a different type of Manner information, translation of the same type of Manner, or omission of Manner (cf. Ibarretxe-Antuñano \& Filipović, 2013; Cifuentes-Férez \& Rojo, 2015). In terms of the constructions used, despite the fact that in the English source text only two constructions are found: 'manner verb + Path in satellite' and 'manner verb + subordinate clause', Galician translators resorted to a wider range of constructions, with constructions with manner verbs being the most common.

The descriptive approaches to translation between languages that are typologically similar or different have often resulted in the identification or proposal of a range of potential translation strategies and in quantification of the degree of Manner and Path information kept in the target text with regard to the source text. Ibarretxe-Antuñano 
On the translation of boundary-crossing events: Evidence from an experiment with German and Spanish translation students

and Filipović (2013) provide an exhaustive summary of the translation strategies identified by different scholars since Slobin's (1996) ground-breaking research, which result in different outcomes ranging from a total transfer of the motion event in terms of Manner and Path to a total omission of the motion event. More recently, Molés-Cases $(2016,2018)$ in her investigations of the translation of Manner of motion in a German into Spanish corpus of children's and young adult literature, presents a proposal of seven translation techniques adapted to Manner, namely, lexical equivalent, paraphrase, modulation, reduction, omission, specification and addition (see Table 1), bridging the gap between translation techniques drawn from translation studies and translation strategies identified in the motion event literature commented above. Although this paper does not deal with translation techniques, a brief mention to them is included in the analysis, in an attempt to shed light on some phenomena (i.e., modulation) encountered in the data.

Table 1. Correspondence between the translation techniques for Manner proposed in the motion literature and the ones proposed by Molés-Cases (2016).

\begin{tabular}{ll}
\hline $\begin{array}{l}\text { Translation techniques adapted to } \\
\text { Manner in the motion literature }\end{array}$ & $\begin{array}{l}\text { Translation techniques adapted to } \\
\text { Manner in Molés-Cases (2016) }\end{array}$ \\
\hline Total translation of Manner of motion & $\begin{array}{l}\text { Lexical equivalence: Manner } \\
\text { information is kept in the TT through } \\
\text { lexical equivalents. } \\
\text { Paraphrase: the TT contains an } \\
\text { explanation about Manner in the ST. }\end{array}$ \\
\hline Partial translation of Manner of motion & Reduction: Manner is partially reduced. \\
\hline Omission of Manner of motion & $\begin{array}{l}\text { Omission (of Manner) } \\
\text { Omission (of motion event including }\end{array}$ \\
\hline Omission of the motion event & Manner) \\
\hline Specification of Manner of motion & $\begin{array}{l}\text { Specification: the TT contains more } \\
\text { specific information about Manner than } \\
\text { the ST. }\end{array}$ \\
\hline Addition of Manner of motion & $\begin{array}{l}\text { Addition (of Manner) } \\
\text { Addition (of motion event including } \\
\text { Translation of Manner of motion by a }\end{array}$ \\
Mifferent sort of Manner & $\begin{array}{l}\text { Modulation: Manner information in the } \\
\text { TT is different from that in the ST. }\end{array}$ \\
\hline
\end{tabular}

Interestingly enough, Molés-Cases $(2016,2018)$ found that the Spanish translation is simpler than the original text in German in terms of Manner, and that motor 
pattern seems to be most affected by translation. Furthermore, her data showed that Manner is lost in almost 30\% of the corpus, but gained in $9 \%$, which suggests that translators are using the technique of compensation (cf. Molina \& Hurtado, 2002) as they could be compensating the loss of Manner in some fragments by specifying Manner details and adding Manner in other parts of the novels. On the whole, her findings are in line with previous research on the translation of motion from satelliteframed into verb-framed languages and point to some advances in the study of the translation of manner of motion events.

Despite the wealth of research on the translation of motion events, no special attention has been given to the translation of boundary-crossing events. Therefore, to our knowledge, the questions still remain unanswered as to whether student translators face any problem when understanding this type of event and whether they translate these events correctly. The following section introduces a study aimed at addressing these issues.

\section{Study: research question, hypotheses and experiment}

\subsection{Research question and hypotheses}

With this piece of research, we attempt to shed light on the translation of English boundary-crossing events taken from narrative texts into German and Spanish. The research question that this contribution aims to answer is the following: Do German and Spanish translation students encounter difficulties in the interpretation and rendering of English boundary-crossing events?

In an attempt to answer this question and drawing on previous research on the translation of motion events, in this study two sets of hypotheses are posited: the former set is related to the translation of boundary-crossing, while the latter refers to the translation of Manner of motion:

\subsection{Translation of boundary-crossing:}

Hypothesis 1a: In the English > German linguistic combination, German translation students are expected to interpret correctly and translate boundarycrossing in most cases. Since both English and German are satellite-framed languages, we predict that student translators will be likely to interpret boundary-crossing correctly and, thus, translate it into German. 
Hypothesis 1b: In the English > Spanish linguistic combination, Spanish translation students are expected to often misinterpret boundary-crossing and do not translate it. Because in Spanish Path is typically encoded in the sentence's main verb, it is hypothesized that student translators will be more likely to focus on translating the main verbs (i.e., manner verbs) and to overlook the boundary-crossing encoded in the prepositional phrases. This hypothesis has been inspired by the continued observation of this phenomenon (loss of boundary-crossing in Spanish translations) in translation classes.

\subsection{Translation of Manner:}

Hypothesis 2a: In the English > German linguistic combination, German translation students are expected to translate Manner in most cases. Because both languages typically use the same lexicalization pattern (i.e., manner verb + Path in a satellite/verb particle), it is expected that German students will be likely to translate all Manner information conveyed in the boundary-crossing events.

Hypothesis 2b: In the English > Spanish linguistic combination, Spanish translation students often omit Manner. Due to the typological differences in the linguistic expression of Manner, it is expected that student translators will be likely to omit, reduce or modulate Manner information in the Spanish translation in comparison with the original in English.

\section{Materials and Method}

The experiment carried out consisted in requesting native German- and Spanishspeaking translation students to translate into their mother tongues five excerpts of narrative texts in English. A total of 73 translation students aged between 19 and 28 and proficiency in English between B2 and C2 participated in the experiment: 20 students from the Universität Leipzig (Germany) and 53 students from the Universidad de Murcia (Spain). ${ }^{1}$ The students had 90 minutes to complete the task using any resource, including online dictionaries or corpora. Background information regarding the source of the texts or the research question was given to the students only after the experiment.

The materials used were five excerpts with a total of around 500 words taken from five novels originally written in English. Except for the fragment from Mockingjay, these excerpts were extracted from the COVALT corpus (Corpus Valencià de Literatura Traduïda, Universitat Jaume I), specifically from the subcorpus of original 
texts in English: http://www.covalt.uji.es. The motion events included in the five excerpts (henceforth, E1, E2, E3, E4, and E5) are listed in Table 1:

Table 2. Excerpts used in the experiment.

\begin{tabular}{|c|c|c|c|}
\hline Excerpts & Source & Author & Year \\
\hline $\begin{array}{l}\text { E1. Aunt Em, badly frightened, threw } \\
\text { open the trap door in the floor and } \\
\text { climbed down the ladder into the } \\
\text { small, dark hole. }\end{array}$ & $\begin{array}{l}\text { The Wonderful } \\
\text { Wizard of } \mathrm{Oz}\end{array}$ & L. Frank Baum & 1900 \\
\hline
\end{tabular}

E2. The next moment, I heard a loud shriek and a crash of something dropping, and she came staggering back into The Ghostly rental Henry James 1948 the room without her light.

\begin{tabular}{llll}
\hline $\begin{array}{l}\text { E3. Suddenly he turned tail and darted } \\
\text { into a crevice in the rock behind him. }\end{array}$ & The Grizzly King & $\begin{array}{l}\text { James Oliver } \\
\text { Curwood }\end{array}$ & 1916 \\
\hline $\begin{array}{l}\text { E4. We skid into a nest with a pair } \\
\text { of soldiers, hunching down behind the } \\
\text { barrier. }\end{array}$ & Mockingjay & $\begin{array}{l}\text { Suzanne } \\
\text { Collins }\end{array}$ & 2010 \\
\end{tabular}

E5. The window was so wet I couldn't see, so I ran downstairs as I was and slipped out the back into the garde and there was the poor fellow at the end The Dead James Joyce 1914 of the garden, shivering.

As can be seen in Table 2, all motion events include Manner and boundarycrossing (encoded in the prepositional phrase 'into + a bounded space'). We decided to focus on this type of Path because Alonso (2016) found that it was a source of major cross-linguistic influence in her research, and we considered that, as this study represents a first approximation to the translation of boundary-crossing events, it would be reasonable just to focus on one type of Path. Furthermore, it should be noticed that whereas E1 depicts downward motion, that is, motion along a vertical axis, E2, E3, E4, and E5 depict motion along a horizontal axis. In our corpus of novels, we just came across one instance of into + vertical axis (i.e., the one in E1); as a consequence, we are aware of the fact that the stimuli in this regard are not balanced. It is also important to highlight that in E2 the lexicalization pattern corresponds to the lexicalization pattern typical of verb-framed languages ("path verb + Manner in adjunct'), as we also wanted to explore whether this could have a facilitating effect for Spanish student translators when understanding and translating the event. 


\section{Results and discussion}

In this section, the results of the experiment will be presented in order to test the hypotheses formulated above.

\section{Translation of boundary crossing (hypotheses $1 \mathrm{a}$ and $1 \mathrm{~b}$ )}

As a reminder, as English and German belong to the same typological group and use the same characteristic lexicalisation pattern for motion, hypothesis 1a stated that German student translators would be more likely to correctly interpret and translate English boundary-crossing events. In contrast, hypothesis $1 \mathrm{~b}$ predicted that Spanish student translators would be more prone to misinterpret boundary-crossing events and, thus, less likely to translate the crossing of boundaries in the target texts as they might be paying more attention to the meaning of the main motion verb (i.e., a manner verb in four of the five English excerpts), which in Spanish typically encodes the core component (i.e., Path) of the motion event. Figure 3 shows the results of the rendering of the boundary-crossing information for each of the five fragments and for the two linguistic combinations:

Figure 1. Results of the experiment: translation of boundary-crossing (\%).

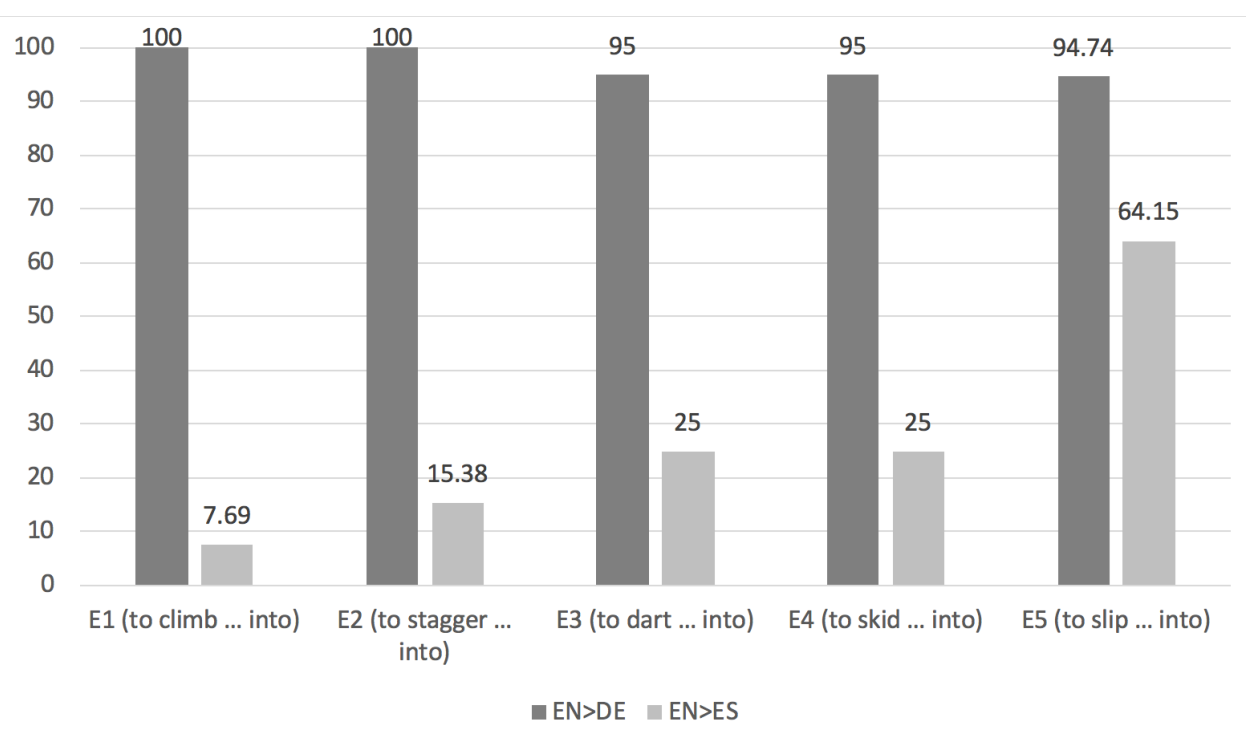

The reader should note that EN $>$ DE stands for English $>$ German translation and EN>ES, for English>Spanish translation. In general, as shown in Figure 1, German students seemed to have identified the boundary-crossing events correctly and they have translated them in most cases; more concretely, they have translated boundary- 
crossing in all cases for E1 and E2, whereas for E3, E4, and E5 the percentage of translation of this information is over $94 \%$ of the target texts. Therefore, in the light of these results, the research hypothesis 1a is confirmed.

E1: ([...] climbed down the ladder into the small, dark hole [...]

[...] und stieg die Leiter in das schmale, dunkle Loch hinab.

And climb.PAST.3SG the.F ladder in the.N.ACC small.N dark.N hole down

'and climbed the ladder into the narrow dark hole down'

[...] und kletterte über die Leiter in das kleine, dunkle Loch hinunter.

And climb.PAST.3SG over the.F ladder in the.N.ACC small.N dark.N hole down

'and climbed over the ladder into the small dark hole down'

As examples 4a) and 4b) illustrate, in the German translations of E1, it is clear that the Figure enters into the hole (here the German preposition in is used) by executing a descending motion (encoded in the verb-particles hinab, hinunter) involving the use of arms and legs (as expressed in the manner verbs steigen and klettern, respectively, and in the action of descending a ladder). If we have a look at other translations from other excerpts (see examples 5 and 6), it can be noticed that once again it is the preposition in that indicates the crossing of a boundary (in eine Spalte, in ein Nest, in den Garten). The fact that the English prepositions into and in (indicating crossing of boundaries) find their direct equivalents in the German preposition in (including the crossing of boundaries as well) could explain the high degree of translation of this type of information.

E2: [...] darted into a crevice in the rock behind him.

[...] und stürzte sich in eine Spalte im Felsen hinter ihm.

And rush.PAST.3SG himself in.ACC a.F crevice in.the.DAT rock behind him

'and rushed into a crevice in the rock behind him'

E3: We skid into a nest with a pair of soldiers [...]

Wir schlüpfen in ein Nest mit einigen Soldaten [...]

We slip.PAST.3PL in.ACC a.N nest with some.DAT soldier.PL

'we slipped into a nest with some soldiers' 
On the translation of boundary-crossing events: Evidence from an experiment with German and Spanish translation students

On the whole, German student translators interpret and translate boundarycrossing in most of their target texts. However, the same does not seem to be the case for the translations by Spanish student translators (see Figure 1). Spanish students seemed to have failed to render the boundary-crossing events in 4 out of the 5 excerpts. Concretely, boundary-crossing was correctly translated by participants in 7.69\% of cases for E1, $15.38 \%$ for E2, and 25\% for E3 and E4. But, they managed to translate it in $64.15 \%$ of the cases for E5; we will deal with this particular fragment later on. These results, overall, provide support for hypothesis $1 \mathrm{~b}$, which stated that Spanish translators in training would be likely to misinterpret boundary-crossing events and, as result, less likely to translate the boundary-crossing information. By way of illustration, example 7 includes two translations for E1, which is the excerpt with the lowest percentage of inclusion of the boundary-crossing. These two Spanish translations describe a character who is going down or descending using a staircase until s/he reaches a small dark hole. The translations indicate that $\mathrm{s} /$ he is going down but not that $\mathrm{s} /$ he gets inside the hole, as the prepositions used by the two Spanish student translators were hasta 'until' and hacia 'towards', which do not indicate a boundary-crossing event.

E1: [...] climbed down the ladder into the small, dark hole [...]

[...] bajó por la escalera hasta el pequeño agujero oscuro.

Descend.PAST.3SG through the.F staircase until the.M small.M hole dark.M

'descended through the staircase until the small hole dark'

[...] descendió por las escaleras hacia el pequeño agujero oscuro.

Descend.PAST.3SG through the.PL stair.PL until the.M small.M hole dark.M

'descended through the stairs towards the small hole dark'

In addition, if we focus on example 8, which includes two translations for E4, it can be observed that, in $8 \mathrm{a}$, the Spanish student translator seems to have focussed on the Manner information conveyed in the sentence's main verb (to skid) by using the manner verb deslizarse 'to slide, to skip', overlooking the fact that the characters indeed crossed a boundary (expressed by the satellite into in the English original text) and ended inside the nest with a pair of soldiers. In example 8b, the Spanish student translator has opted for a path verb dirigirse 'to direct oneself' instead of a manner verb. Because the path verb implies that the Figure reaches the Ground or reference object, but not that s/he crosses a boundary, this translation omits both the Manner information and the boundary-crossing. 
E4: We skid into a nest with a pair of soldiers [...]

Entonces nos deslizamos hacia uno de los nidos con un par de soldados [...]

Then we.REFL skid.1PL towards one of the.M.PL nest.PL with a pair of soldier.PL

'Then we skid towards one of the nests with a pair of soldiers'

Nos dirigimos a un nido con un par de soldados

We.REFL direct.PAST.1PL to a nest with a pair of soldier.PL

'we directed ourselves to a nest with a pair of soldiers'

In general, the examples discussed here from E1 and E4 indicate that Spanish translators in training seem to have problems with understanding and translating boundary-crossing events. It does not appear to be clear for Spanish participants that the characters ended inside a bounded space (i.e., a hole or a nest). However, to our surprise, in E5 ([...] I ran downstairs as I was and slipped out the back into the garden $[\ldots])$, more than $60 \%$ of the Spanish participants managed to adequately translate the boundary-crossing event. The question that arises here is why E5 yielded more proper or satisfactory translations. A plausible explanation might be that the context may have played a role for the correct interpretation of the boundary-crossing event in this case, since it is very clear that the character leaves the house and goes into the garden. In spite of the fact that for E5 the boundary-crossing was translated by around $60 \%$ of Spanish participants, overall, our data for E1, E2, E3 and E4 seem to provide support for our research hypothesis $1 \mathrm{~b}$, which stated that in the English > Spanish linguistic combination, Spanish translation students would often misinterpret boundarycrossing and would not translate it.

\section{Translation of Manner (hypotheses $2 a$ and 2b)}

Hypothesis 2a predicted that German student translators would be likely to translate most of the Manner information expressed in the English boundary-crossing events, whereas hypothesis $2 \mathrm{~b}$, on the contrary, stated that their Spanish counterparts would be more likely to omit, reduce, or modulate Manner information. Figure 2 displays the data regarding the degree of Manner lost in each of the five excerpts and in both translation scenarios (English>German and English>Spanish): 
On the translation of boundary-crossing events: Evidence from an experiment with German and Spanish translation students

Figure 2. Results of the experiment: loss of Manner (\%).

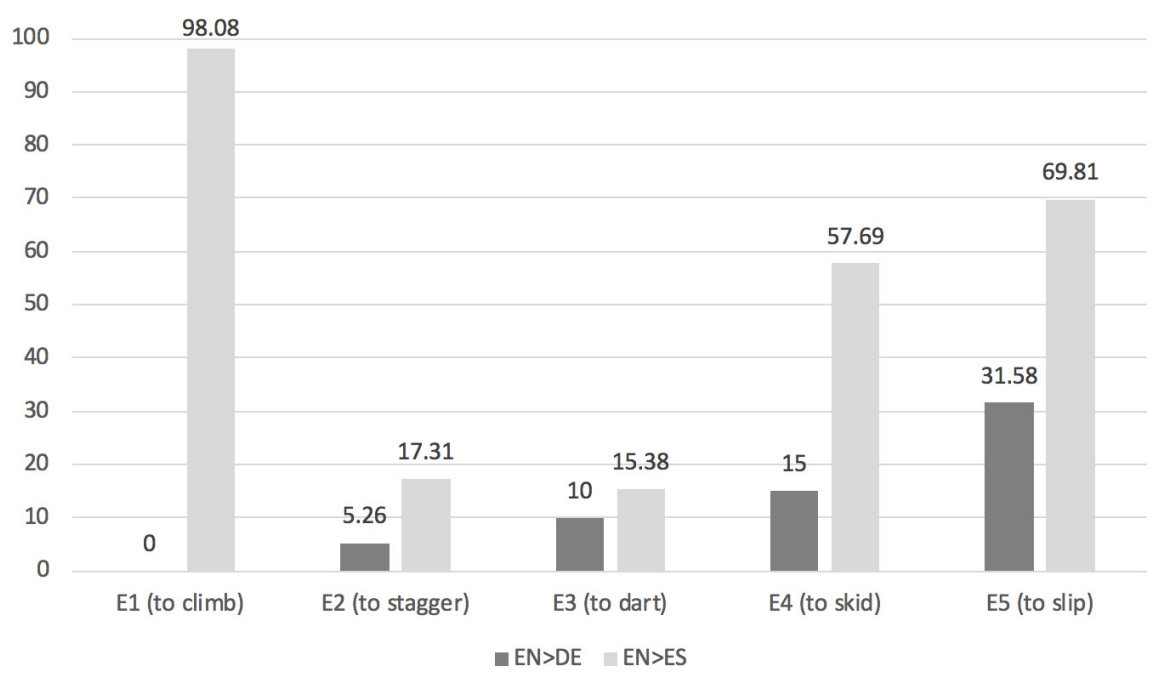

On the one hand, it can be observed that, on the whole, the amount of Manner lost in the German translations is quite low: much less than $16 \%$ for 4 out of the 5 excerpts and less than 32\% for E5. Therefore, these data support research hypothesis $2 \mathrm{a}$ of this study, which stated that in the English > German linguistic combination, German translation students would translate Manner in most cases. The unexpected loss of Manner noticed in the translation of E5 into German deserves, however, special attention. Here, the English original fragment contained the English manner verb to slip but Manner is missing in around 32\% of the German translations.

E5: [...] I ran downstairs as I was and slipped out the back into the garden [...]

[...] so rannte ich ohne Weiteres die Treppe runter durch die Hintertür in den Garten [...]

So run.PAST.1SG I without further.ado.N the.F stair down through the.F back.door in the.ACC garden

'so I ran just like that the stairs down through the back door into the garden'

[...] also rannte ich runter, raus und zurück in den Garten [...]

so run.PAST.1SG I down out and back in the.ACC garden

'so I ran down, out and back into the garden'

[...] also rannte ich so wie ich gekleidet war runter und in den Garten [...]

so run.PAST.1SG I as how I dress.PTCP be.PAST down and in the.ACC garden

'so I ran just like I was dressed down and into the garden' 
As can be seen in the previous examples (9a, 9b, 9c), here the students have focused on the first motion event (I ran downstairs), in general translated by the German equivalent rannte ich runter, and they have omitted the second motion event (slipped out the back into the garden), which was the event including both boundarycrossing and Manner. This unexpected loss of Manner could be due to the following circumstances: a) the sample used is small - the translations of 20 participants were analysed -, and $31.58 \%$ of the omissions corresponds in fact to 6 cases of omission; b) this is a complex construction containing two motion events and students seem to have devoted greater attention to the first event; and c) the German lexical equivalents of slip (e.g., rustchen, gleiten, schlittern, sich schleichen, schlüpfen) are far less common in this language than the verb rennen 'run' (the comparison of frequencies was tested in the following corpora: COVALT (http://www.covalt.uji.es.), DWDS (https://www. dwds.de) and PAGES (https://www.corpuspages.eu)), which seems a more accessible option when translating this complex construction.

Despite the previous exception, in the German translations students tended to render most of the Manner information encoded in the English manner verbs. Examples 10 and 11 illustrate instances of the total translation of Manner in the German target texts. Here Manner is expressed in the target texts through the manner verbs klettern 'to climb' and flitzten 'to dart'. In addition, in both cases boundarycrossing is expressed by prepositional phrases introduced by the preposition in, and it is the context which further indicates that in example 10 motion has a vertical axis.

E1: [...] climbed down the ladder into the small, dark hole.

[...] und kletterte die Leiter in das kleine, schwarze Loch.

And climb.PAST.3SG the.F ladder in the.N.ACC small.N dark.N hole

'and climbed the ladder into the small black hole'

E3: [...] darted into a crevice in the rock behind him.

[...] und flitzte in eine Spalte im Felsen hinter ihm.

And dash.PAST.3SG in a.F crevice in.the.DAT rock behind him

'and dashed into a crevice in the rock behind him'

On the other hand, as expected due to the typological differences between English and Spanish, it can be seen that far more Manner is lost (not translated) in the Spanish target texts than in the German ones. More concretely, Manner is lost to a great extent in 3 out of the 5 excerpts, namely, E1 (98.08\%), E4 (57.69\%), and E5 
On the translation of boundary-crossing events: Evidence from an experiment with German and Spanish translation students

(69.81\%). This loss of Manner is even more notable in the case of E1 ([...] climbed down the ladder into the small, dark hole), where the Figure climbs down into a dark hole (i.e., vertical axis). This finding suggests that for this vertical boundary-crossing event in which Manner of motion is not rapid or sudden, Manner has been sacrificed in favour of Path information. As shown in example 7, the English manner verb to climb has been translated with the Spanish path verbs bajar and descender, both of which can be rendered into English as 'to descend'. In contrast, for E2 and E3 the degree of Manner loss is not very high (17.31\% and $15.38 \%$, respectively). As indicated earlier, E2 ([...] she came staggering back into the room without her light) presents the lexicalization pattern typical of verb-framed languages, which seems to have had a facilitating effect for Spanish participants leading to a higher degree of translation of Manner with respect to other fragments. The plausible reasons underlying the results of the translation of E3 ([...] darted into a crevice in the rock behind him) might be found in the literature on boundary-crossing motion events (Naigles et al., 1996; Özcaliskan, 2015; Alonso, 2016). This motion event includes the manner verb to dart, which encodes fast motion and, in this case, the motion is along a horizontal axis. Since the literature has shown that Spanish allows the use of manner verbs in fast vertical motion, this would help explain the translation of Manner here (though the motion depicted in E3 takes place along a horizontal axis). All in all, these data provide only partial support for hypothesis $2 \mathrm{~b}$, which predicted that in the English > Spanish linguistic combination, Spanish translation students would often omit Manner.

Focussing now on the loss of Manner information, as discussed earlier for example $8 \mathrm{~b}$, the Manner information encoded in to skid is totally omitted and the path verb dirigirse 'to direct oneself' is used. Similarly, in example 12, where we focussed on the second motion event encoding boundary-crossing and Manner, the English manner verb to slip has been translated by the Spanish path verb salir 'to exit' in 12 a and by the deictic motion verb ir 'to go' in $12 \mathrm{~b}$, resulting in the total omission of the Manner information of this particular motion event.

E5: [...] I ran downstairs as I was and slipped out the back into the garden [...]

[...] así que bajé corriendo por las escaleras y sali al jardín.

So that descend.PAST.1SING run.GER by the.F.Pl stair.PL and exit. PAST.1SING to.the.M garden

'so that I descended running by the stairs and exited to the garden'

[...] y como iba bajé corriendo las escaleras y fui hacia la parte de atrás del jardín. 
and as be.PAST.1SING descend.PAST.1SING run.GER the.F.Pl stair.PL and go.PAST.1SING towards the.F part of behind of.the garden

'so as I was I descended running the stairs and I went towards the back part of the garden'

Although this study did not aim to explore in detail the translation techniques used when rendering manner verbs, it is interesting to draw attention to the fact that Spanish participants, when they opted for including Manner in their translations, produced more instances of modulation of Manner (that is, the Manner information expressed in the target text is different from that included in the source text) than their German counterparts (18 modulations in Spanish vs. 3 instances in German; 33.96 \% vs. 15\%). This finding aligns well with the observations of Ibarretxe-Antuñano (2003) regarding the translation of English manner verbs by Spanish translators. Table 3 presents the cases of modulation of Manner:

Table 3. Results of the experiment: modulation of Manner.

\begin{tabular}{|c|c|c|c|}
\hline$E$ & Manner-verb & $\mathrm{EN}>\mathrm{DE}$ & $\mathrm{EN}>\mathrm{ES}$ \\
\hline 1 & to $\operatorname{climb}$ & 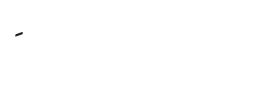 & $\begin{array}{l}1 \\
\text { (deslizarse, 'to slip') }\end{array}$ \\
\hline 2 & to stagger & $\begin{array}{l}1 \\
\text { (sich eilen, 'to } \\
\text { hurry') }\end{array}$ & $\begin{array}{l}8 \\
\text { [volver ('return') + ADJ/ADV: } \\
\text { asombrada ('shocked'), } \\
\text { perpleja ('puzzled'), } \\
\text { pasmada ('astonished'), } \\
\text { desconcertada('disconcerted'), } \\
\text { atónita ('stunned'), } \\
\text { impactada ('shocked')] }\end{array}$ \\
\hline 3 & to dart & - & $\begin{array}{l}2 \\
\text { (saltar, 'to jump') }\end{array}$ \\
\hline 4 & $\begin{array}{l}\text { to skid } \\
\text { (in the sense of } \\
\text { sliding) }\end{array}$ & - & $\begin{array}{l}1 \\
\text { (derrapar, 'to skid') }\end{array}$ \\
\hline 5 & to slip & $\begin{array}{l}2 \\
\text { (gehen, 'to walk') }\end{array}$ & $\begin{array}{l}6 \\
\text { (apresurarse, 'to hurry'; correr, 'to run') }\end{array}$ \\
\hline & Total & $3(15 \%)$ & $18(33.96 \%)$ \\
\hline
\end{tabular}


As shown in Table 3, there has been a modulation of the manner verbs in the Spanish source texts across the five excerpts. This modulation was most frequent for E2 where the verb to stagger was modulated on eight occasions in the Spanish target texts by using the verb volver 'to return' followed by adjectives or adverbs providing information about the state of mind of the character such as asombrada 'shocked', desconcertada 'disconcerted', and so on. In contrast, as stated above, only three instances of the technique of modulation can be found in the German target texts: to stagger was modulated as sich eilen 'to hurry' in one case, and to slip as gehen 'to walk' in two instances.

\section{Conclusions}

The study presented in this paper has explored the issue of how German and Spanish translators in training dealt with the translation of English boundary-crossing events into their respective L1, that is, their mother tongues. This research represents a first step in the investigation of how boundary-crossing events are interpreted or understood and translated from English, a satellite-framed language, into two languages (i.e., Spanish and German) which belong to different typological groups. Our findings reveal that, unlike German translators in training, Spanish translators in training often fail to translate the boundary-crossing depicted in the excerpts and seem to face problems regarding the correct interpretation and rendering of boundarycrossing events with Manner information, suggesting that they do focus on translating the Manner in which the characters move, neglecting, as a result, the transfer of boundary-crossing information. In addition, our results suggest that Spanish translators in training are more likely to omit Manner information and to modulate Manner more often in their target texts than are German student translators.

In general, the paper provides insights into the role that the context of the excerpt can play in the correct interpretation and, therefore, the accurate rendering of the boundary-crossing event. Additionally, in line with prior research on boundarycrossing events, our data also indicate that the intrinsic nature of the events, namely, the speed as well as the vertical or horizontal orientation of the motion are relevant facets to consider when investigating this issue. Our results for the translation of the vertical boundary-crossing event showed that it was the event with the lowest rate of translation of boundary-crossing and the highest loss of Manner information in Spanish. Regarding the translation of quick or rapid motion events, it was also noticed that Spanish translators were more likely to include Manner information in their translations than with other types of motion events.

Like any piece of research, this paper would not be complete without pointing out some limitations related to the methodological choices made. As clearly stated 
in Section 3, the selected excerpts only included boundary-crossing events with the preposition into + a bounded space, and four of the five excerpts depicted motion along a horizontal axis with just one excerpt including a vertical axis. As some differences were noted between events depicting motion along a vertical axis and those along a horizontal one, a more balanced sample of events would be desirable in future followups.

Thinking about future lines of research, it would be interesting to compare our data with the results of the translation of other types of boundary-crossing, such as the ones describing coming out of a bounded space or crossing a space. Furthermore, greater attention should be paid to the difference between the vertical and horizontal axes, as well as to the duration or time span of the event so as to get a wider picture of the potential effects of all these factors on the interpreting and rendering of boundarycrossing events. Finally, it would be worthwhile to use a larger corpus of original and translated texts in order to further explore the impact of the nature of the narrated event together with the impact of linguistic framing in other verb-framed and satelliteframed languages.

On the whole, the research presented here has some pedagogical implications as it would be highly desirable for students in translation and interpreting degrees to receive formal instruction on typological differences in the lexicalization of motion events, with special attention to boundary-crossing events.

\section{Acknowledgements}

We are thankful to Michele I. Feist for her helpful feedback. We are also very grateful to the students that participated in the experiment and to our colleagues Martina Emsel, Constanze Gräsche, Elija Lutze (Universität Leipzig) and Francisco Pérez Escudero (Universidad de Murcia), for their help in carrying out the experiment at both universities.

\section{References}

Alonso Alonso, R. (2016). Cross-linguistic influence in the interpretation of boundary-crossing events in L2 acquisition. Review of Cognitive Linguistics, 14(1), 161-182.

Alonso Alonso, R. (2018). Translating motion events into typologically distinct language". Perspectives, 26(3), 357-376.

Aurnague, M. (2011). How motion verbs are spatial: The spatial foundations of intransitive motion verbs in French. Lingvisticae Investigationes, 34(1), 1-34. 
On the translation of boundary-crossing events: Evidence from an experiment with German and Spanish translation students

Aske, J. (1989). Path predicates in English and Spanish: A closer look. In K. Hall, M. Meacham, \& R. Shapiro (Eds.), Proceedings of the fifteenth annual meeting of the Berkeley Linguistics Society (pp. 1-14). Berkeley: Berkeley Linguistics Society.

Cadierno, T. (2010). Motion in Danish as a second language: Does the learner's L1 make a difference? In Z. Han \& T. Cadierno (Eds.), Linguistic relativity in SLA: Thinking for speaking. (1-33) Clevedon: Multilingual Matters.

Cadierno, T., \& Ruiz, L. (2006). Motion events in Spanish L2 acquisition. Annual Review of Cognitive Linguistics, 4, 183-216. doi: 10.1075/arcl.4.08cad

Cadierno, T., \& Robinson, P. (2009). Language typology, task complexity and the development of L2 lexicalization patterns for describing motion events. Annual Review of Cognitive Linguistics, 7, 245-276. doi: 10.1075/arcl.7.10cad

Cappelle, B. (2012). English is less rich in Manner-of-motion verbs when translated from French. Across Languages and Cultures, 13(2), 173-195.

Cerda, J. P. (2010). Estrategias utilizadas en la traducción inversa español-inglés de verbos de movimiento: un estudio en lingüistica cognitiva [Strategies in the inverse translation Spanish- English of motion verbs: a study in cognitive linguistics] (Unpublished master's thesis). Universidad de Concepción, Chile.

Cifuentes-Férez, P. (2015). Thinking-for-translating: Acquisition of English physical motion constructions by Spanish translators in training. Cognitive Linguistic Studies, 2(2), 302-329.

Cifuentes-Férez, P. (2017). The Impact of Typological Differences on the Perceived Degree of Dynamicity in Motion Events. Trans, 21, 169-185.

Cifuentes-Férez, P. (2018). Metodologías de investigación en movimiento y traducción. In A. Rojo (Ed.), La investigación en traducción: una revisión metodológica de la disciplina. Barcelona: Anthropos. 22-40.

Cifuentes-Férez, P., \& Rojo, A. (2015). Thinking for translating: A think-aloud protocol on the translation of manner-of-motion verbs. Target, 27(2), 273-300.

Feist, Michele I. (2016). Minding your manners: linguistic relativity in motion. Linguagem em (Dis)curso, 16(3), 591-602.

Filipović, L., \& Hijazo-Gascón, A. (2018). Interpreting Meaning in Police Interviews: Applied Language Typology in a Forensic Linguistics Context. Vigo International Journal of Applied Linguistics, 15, 67-104.

Hijazo-Gascón, A. \& Ibarretxe-Antuñano, I. (2013). Las lenguas románicas y la tipología de los eventos de movimiento. Romanische Forschungen, 125, 467-494. 
Iacobini, C. \& Fagard, B. (2011). A diachronic approach to variation and change in the typology of motion event expression. A case study: From Latin to Romance. Faits de langue-Les Cahiers, 3, 152-171.

Ibarretxe-Antuñano, I. (2003). What Translation Tells Us about Motion: A Contrastive Study of Typologically Different Languages. International Journal of English Studies, 3(2), 151-166.

Ibarretxe-Antuñano, I. (2004). Motion Events in Basque Narratives. In Strömqvist, S. \& L. Verhoeven (Eds.), Relating Events in Narrative: Typological and Contextual Perspectives (pp 89-111) New Jersey: Lawrence Erlbaum.

Ibarretxe-Antuñano, I. \& Filipović. L. (2013). Lexicalisation patterns and translation. In Rojo, A. \& I. Ibarretxe-Antuñano (Eds.), Cognitive Linguistics and Translation (pp. 251-282). Germany: Mouton de Gruyter.

Kopecka, A. (2010). Motion Events in Polish: Lexicalization Patterns and the Description of Manner. In Hasko, V., \& R. Perelmutter (Eds.), New Approaches to Slavic Verbs of Motion. (pp 225-247) Amsterdam: John Benjamins.

Lewandowski, W. (2018). A typological approach to the encoding of motion events. In Gómez González, M.aA., \& J. Lachlan Mackenzie (Eds.), The Construction of Discourse as Verbal Interaction. Pragmatics and Beyond New Series, 296. (pp 45-75) Amsterdam: John Benjamins.

Lewandowski, W. \& Mateu, J. (2016). Thinking for translating and intratypological variation in satellite-framed languages. Review of Cognitive Linguistics, 14(1), 185-208.

Martínez-Vázquez, M. (2013). Intralinguistic variation in the expression of motion events in English and Spanish. Lingue e Linguaggi, 9, 143-156.

Molés-Cases, T. (2016). La traducción de los eventos de movimiento en un corpus paralelo alemán-español de literatura infantil y juvenil. Frankfurt am Main: Peter Lang.

Molés-Cases, T. (2018). Some advances in the study of the translation of manner of motion events. Review of Cognitive Linguistics, 16(1), 152-190.

Molina, L. \& Hurtado Albir, A. (2002). Translation Techniques Revisited: A Dynamic and Functionalist Approach. Meta: Translators' Journal, 4, 498-512.

Özcaliskan, S. (2015). Ways of crossing a spatial boundary in typologically distinct languages. Applied Psycholinguistics, 36, 485-508.

Naigles, L., Eisenberg, A. R., Kako, E. T., Highter, M., \& McGraw, N. (1998). Speaking of motion: verb use in English and Spanish. Language and Cognitive Processes, 13(5), 521-549. 
On the translation of boundary-crossing events: Evidence from an experiment with German and Spanish translation students

Robinson, P., \& Ellis, N. C. (2008). Conclusions: Cognitive linguistics, second language acquisition and L2 instruction - Issues for research. In P. Robinson \& N. C. Ellis (Eds.), Handbook of cognitive linguistics and second language acquisition (pp. 489-546). New York: Routledge.

Slobin, D. I. (1996). From "thought and language" to "thinking for speaking". In Gumperz, J. \& S. Levinson (Eds.), Rethinking linguistic relativity: Studies in the social and cultural foundations of language, vol. 1. (pp 70-96) Cambridge: Cambridge University Press.

Slobin, D. I. (1997). Mind, code and text. In J. Bybee, J. Haiman, \& S. A. Thompson (Eds.), Essays on language function and language type: Dedicated to T. Givón. (pp 437-467) Amsterdam: John Benjamins.

Slobin, D. I. (2003). Language and Thought Online: Cognitive Consequences of Linguistic Relativity. In Gentner, D., \& S. Goldin-Meadow (Eds.), Language in Mind: Advances in the Study of Language and Thought. (pp 157-192)Cambridge, MA: MIT Press.

Slobin, D. I., \& Hoiting, N. (1994). Reference to movement in spoken and signed languages: Typological considerations. Proceedings of the Berkeley Linguistics Society, 20, 487-505.

Sugiyama, Y. (2005). Not all verb-framed languages are created equal: The case of Japanese. Proceedings of the 31st Annual Meeting of Berkeley Linguistics Society, 299-310.

Talmy, L. (1985). Lexicalization patterns: Semantic structure in lexical forms. In Shopen, T. (Ed.), Language typology and lexical descriptions: Vol. 3. Grammatical categories and the lexicon (pp. 36-149). Cambridge: Cambridge University Press.

Talmy, L. (1991). Path to Realization: A Typology of Event Conflation. Proceedings of the 17th Annual Meeting of the Berkeley Linguistics Society, 480-519.

Talmy, L. (2000). Toward a cognitive semantics: Vol. II: Typology and process in concept structuring. Cambridge, MA: MIT Press. 
